\title{
COVID-19 Pandemisine Pediatrik Yaklaşım
}

\author{
Hakan KARDEŞ ๑ $₫$, Zühal ÖRNEK ๑ \\ ${ }^{1}$ Zonguldak Bülent Ecevit Üniversitesi Tip Fakültesi Çocuk Sağlığı ve Hastalıkları Anabilim Dalı, Zonguldak, Türkiye \\ Bu makaleye yapılacak atıf: Kardeș H, Örnek Z. COVID-19 Pandemisine Pediatrik Yaklaşım. Türk Diyab Obez 2020;2: 170-176.
}

\begin{abstract}
ÖZ
Yeni koronavirüs hastalığı (2019-nCoV, COVID-19) ilk kez Çin’de 2019 yllı sonlarında bildirilmiştir. Kısa sürede tüm dünyayı etkilemiş ve pandemi olarak kabul edilmiştir. Çocuklarda kliniği erişkinlere göre hafif seyretmektedir ve çocuklarda prognoz iyidir. Tanısı gerçek zamanlı polimeraz zincir reaksiyonu testi ile konulur. Çocuklarda spesifik laboratuvar testi yoktur. Bağışıllığı baskılanmış ve altta yatan hastalığı olan çocuklarda hastalık daha ağır seyreder. Şu an için çocuklarda COVID-19 enfeksiyonuna yönelik tedavi için yeterli ve kesinleşmiş veriler bulunmamaktadır. Bu derlemede güncel literatür bilgileri ışığında COVID-19 hastalığının çocuklarda epidemiyolojisi, kliniği, tanısı, tedavi yaklaşımları ve olası sık görülen temas durumlarına karşı korunma önlemlerinin sunulması amaçlanmıştır.
\end{abstract}

Anahtar Sözcükler: Koronavirus, COVID-19, Çocuk, Pediatri

\section{Pediatric Approach to COVID-19 Pandemic}

\begin{abstract}
The novel coronavirus disease (2019-nCoV, COVID-19) was first reported in China in late 2019. It has impacted the world in a short time and characterized as a pandemic. The clinical picture in children is milder than adults and prognosis are good in children. The diagnosis is made by a real-time polymerase chain reaction test. There is no specific laboratory test for COVID-19 infection in children. The disease progresses more severely in children with an underlying condition and immunocompromised children. There are currently no sufficient and conclusive data on treatment for COVID-19 infection in children. This review aims to present the epidemiology, clinical picture, diagnosis, treatment approaches, and possible preventive measures of COVID-19 disease in children in light of the current literature.
\end{abstract}

Key Words: Coronavirus, COVID-19, Child, Pediatrics

\section{GíRIS}

Koronavirüs, hayvanlarda ve insanlarda önemli patojenlerden birisidir. Çin'in Hubei eyaleti Wuhan kentinde 2019 yılı sonunda salgın şeklinde ortaya çıkan pnömoni olgularında yeni bir tipi tanımlanmış ve ardından hızla yayılarak tüm dünyada salgınlara yol açmıştır(1). Ocak 2020'de Dünya Sağlık Örgütü (DSÖ) ateş, öksürük, solunum sıkıntısı, bulantı, ishal gibi semptomlarla başvuran bu hastalardaki etkeni daha önce insanlarda tespit edilmemiş yeni bir koronavirüs (2019- nCoV) olarak tanımlamış ve hastalık
COVID-19 olarak adlandırılmıştır. Virüs SARS CoV'e çok yakın genetik benzerliğinden dolayı SARS-CoV-2 olarak isimlendirilmiştir. Hastalık başlangıçta Wuhan Güney Çin deniz ürünleri pazarı çalışanlarında görülmekte iken, kısa sürede dünya geneline yayılmış, 11 Mart 2020 tarihinde COVID-19 DSÖ tarafından pandemi olarak kabul edilmiştir $(2,3)$. Bu yazıda tüm dünyada etkisini sürdüren COVID19 pandemisinin çocukluk yaş grubundaki etkilerinin, klinik özelliklerinin ve tedavi yaklaşımlarının güncel literatür ışığında sunulması amaçlanmıştır.

ORCID: Hakan Kardeș / 0000-0002-0553-7072, Zühal Örnek / 0000-0001-9252-1652 


\section{EPIDEMIYOLOJI}

COVID-19 hastalığı hakkında yapılan çalışmalar ve yayınlanan veriler, hastalığın çocuklara nazaran erişkinlerde daha yaygın gözlemlenmesi ve daha ağır seyretmesi nedeni ile daha çok erişkin odaklıdır (4). Çin' in Shenzen kentinde yaşayan ve ailesi kısa süre önce Wuhan kentini ziyaret etmiş olan 10 yaşında erkek çocuk 20 Ocak 2020 tarihinde literatürdeki ilk pediatrik COVID-19 olgusu olarak bildirilmiştir (5). Bununla birlikte, 7-15 Ocak 2020 tarihleri arasinda solunum yolu enfeksiyonları nedeniyle hastaneye yat1rilan 366 çocuğun retrospektif olarak değerlendirildiği bir başka çalışmada, 6 çocukta $(\% 1,6)$ COVID-19 saptandığ 1 ve hastalık belirtilerinin 2-8 Ocak 2020 tarihleri arasında başladığının tespit edildiği bildirilmiştir $(4,6)$. Salgının erken evrelerinde pediatrik popülasyonun nadiren tetkik edildiği ve bu nedenle de pediatrik olgu sayıları ile ilgili verilerin sinırlı olduğuna dikkat çekilmiştir. 31 Ocak 2020 tarihine kadar Çin'de doğrulanan 11.791 COVID-19 olgusunun 74 'ünün $(\% 0,6)$ yaşları 1,5 ay ile 18 yaş arasında pediatrik hasta olduğu ve bu hastalar ile ilgili olgu kaynağının $\% 56$ ile aile içi temas olduğu bildirilmiştir $(4,7)$. Dong ve ark. tarafından Nisan 2020 tarihinde yayınlanan, 16 Ocak 2020 'den 8 Şubat 2020'ye kadar Çin Hastalık Kontrol ve Önleme Merkezince takibe alınan COVID-19'lu 2135 pediatrik hastanın retrospektif incelemesinde, hastaların 728 'i $(\% 34,1)$ laboratuvar onayll, 1.407'si $(\% 65,9)$ şüpheli olgu olarak sınıflandırılmıştır. Tüm pediatrik hastaların ortanca yaşının 7 ve bu hastalar arasında 1.208 olgunun $(\% 56,6)$ erkek olduğu, kız ve erkek çocuklar arasında istatistiksel olarak anlamlı bir fark saptanmadığ 1 bildirilmiştir (8). Çin Hastalık Kontrol ve Önleme Merkezi 11 Şubat 2020 tarihine kadarki hasta verilerini referans aldığı literatürde, 44.672 laboratuvar teyitli hastanın $965^{\prime}$ inin $(\% 2,1)$ pediatrik yaş grubunda hasta olduğu ve pediatrik hastalar arasında $1(\% 0,18)$ ölüm gerçekleştiği yayınlanmıştır (9). Bi ve ark. nın COVID-19 hasta ve temaslıları ile yaptığ çalışmada pediatrik hasta oranı \%8,1 olarak saptanmış çocukların SARS-CoV-2 ile enfekte olma olasilıklarının yetișkinler kadar olası olduğu bildirilmiştir (10). Avrupa'da COVID-19 hastalığından en çok etkilenen ülkelerin başında gelen İtalya'da 31 Mart 2020'ye kadar toplam 101.739 pozitif olgu, toplam 11.591 ölüm bildirilmişken, tespit edilen çocuk hasta sayısı $1.226(\% 1,3)$ olarak açıklanmıştır (11). ABD'de 12 Şubat - 2 Nisan 2020 tarihleri arasında 149.760 hastanın laboratuvar onaylı COVID-19 tanısı aldığı, yaş bilgisi olan 149.082 olgunun 2.572 'sinin $(\% 1,7) 18$ yaşın altındaki çocuklar olduğu saptanmıştır. Aynı çalışmada pediatrik olgular arasında 3 ölüm olduğu bildirilmiştir (12).

Ülkemizde ilk olgu 11 Mart 2020 de bildirilmiştir. İlk olgu görülmeden önce 22 Ocak 2020 de T.C. Sağlık Bakanlığ 1
Bilimsel Danışma Kurulu ilk toplantısını gerçekleştirmiş, ülkemizde salgının zararlarının azaltılması, salgının sınırlandırılması ve baskı altına alınması ile ilgili çalışmalara başlamıştır. T.C. Sağlık Bakanlığı Halk Sağlığ 1 Genel Müdürlügü tarafından COVID-19 hastalığı, olgu tanımları, hasta yönetim algoritmaları ve izlenmesi gereken stratejiler hakkında SARS-CoV2 Enfeksiyonu Rehberi oluşturulmuştur. Bu rehber, hastalık hakkında edinilen bilgiler ışığında DSÖ önerileri ve hastalık hakkındaki bilimsel gelişmeler doğrultusunda güncellenmektedir (3).

\section{BULAȘMA}

Hastalık insandan insana ön planda damlacık yoluyla bulaşır. Ayrıca enfekte kişinin öksürme, hapşırma yoluyla saçtığı damlacıkların olduğu nesnelere, kapı kollarına ya da oyuncaklara diğer kişilerin elleri ile temas etmesi sonrası bu kişilerin ellerini ağız, burun veya göz mukozasına götürmesi ve temas etmesi ile de bulaşabilmektedir $(3,7)$. Gebelikte intrauterin anneden fetusa vertikal geçiş bildirilmemiştir (13). Olgu serileri incelendiğinde COVID-19 hastalığının median inkübasyon süresinin 5,2 gün olduğu saptanmış olup, bulaşıcıllğ̆ın semptom başlangıcından 2-3 gün önce başladığı tahmin edilmektedir(14). Çocukların hastalığa daha çok ev içi temas ile maruz kaldığı bildirilse de, ülkemizde de olduğu gibi okullarda eğitime ara verilmesi ve çocukluk yaş grubundaki sokağa çıkma yasağı gibi uygulamaların istatistiksel veriler üzerine etkisi göz ardı edilmemelidir. Asemptomatik kişilerin de virüs ile enfekte oldukları ve bu kişilerin de bulaştırıcılıkta rol oynadıkları bilinmektedir. Çocuklarda kliniğin erişkinlere göre hafif seyretmesinin, çocukların bulaştırıcılıkta ihmal edilmesine sebebiyet vereceği unutulmamalıdır. Mevcut veriler enfekte çocukların hastalığı geçirmesinden haftalar sonra hâlen dışkıları ile virüsü yayabildiklerini göstermektedir (15). Bu durum tuvalet ya da hijyen eğitimi olmayan bebek ve çocuklarla ev içi, kreş ya da okullarda hastalığın yayılması açısından risk oluşturabilir.

\section{ÇOCUKLARDA KLINIIK ÖZELLIIKLER}

Salgının başlangıç döneminden günümüze kadar yayınlanan literatürler değerlendirildiğinde çocuklarda klinik tablonun erişkinlere göre daha hafif seyirli olduğu ve çocukların sıklıkla hastalık başladıktan 1-2 hafta sonra tamamen iyileştikleri bildirilmektedir (7). Virüs ile enfekte çocukların bir kısmı tamamen asemptomatik olabildikleri gibi, semptomu olan çocuklarda ateş (\%41,5-\%56) ve öksürük (\%48,5\%54) başta olmak üzere, halsizlik, karın ağrısı, bulantı, ishal gibi şikayetlerin görüldüğü bildirilmiştir $(7,12,16)$. Çin'de yayınlanan ve 2.143 çocuk hastayı içeren geniş çaplı çalışmada olgularm klinik olarak \%4,4 asemptomatik, \%50,9 hafif, \%38,8 orta, \%5,2 ağır, \% 0,6 kritik olduğu, ağır ve 
kritik olguların daha çok 1 yaş altında görüldüğü vurgulanmıştır (8). Wuhan Çocuk Hastanesi'nin yayınladığı bir başka olgu serisinde hastaların \%19'unun üst solunum yolu enfeksiyonu bulgularının olduğu, \%65'inin pnömonisi olduğu bildirilmiştir (16). ABD verileri de Çin verileri ile benzerlik göstermektedir. Çocukların \%73'ünün ateş, öksürük, solunum sıkıntısı semptomlarından en az biri ile başvurdukları, altta yatan hastalığı olan çocukların (\%23) ve 1 yaş altı çocukların (\%62) yüksek oranda hastaneye yatış oranı olduğu bildirilmiştir. Çocuklarda altta yatan hastalık olarak eşlik eden kronik akciğer hastalığı, konjenital kalp hastalığı, immünsupresyon, obezite, kötü kontrollü tip 1 diabetes mellitus, nöromusküler hastalık ve preterm doğum öyküsü durumunda kliniğin daha ağır seyredebildiğine dikkat çekilmiştir (12).

COVID-19'un çocuklarda yetişkinlere göre daha nadir görülmesi ve hafif klinik tablo ile seyretmesinin nedeni tam olarak açıklığa kavuşturulamamıştır. Çocukların sosyal yaşamları nedeniyle viral yüke daha az maruz kalmaları, sigara ve hava kirliliğine maruz kalma sürelerinin kısalığı, anjiyotensin dönüştürücü enzim-2 ekspresyon farklılıkları, sitokin firtınasının çocuklarda nadir izlenmesi gibi faktörlerin patogenezde önemli rol oynadığı düşünülmektedir $(17,18)$. BCG aşısının farelerde influenzaya karşı nonspesifik immün yanıtla koruma sağladığı bildirilmiş, düzenli aşılanan çocukların COVID-19 hastalığını benzer mekanizma ile hafif semptomlarla geçirmekte olabileceği vurgulanmıștır (7).

Çocuklarda son dönemde Kawasaki hastalığına benzer klinik tablo izlenen hastalar bildirilmiştir. Pediatrik inflamatuar multisistem sendromu (PIMS) COVID-19 ilişkili nadir fakat hayatı tehdit edici ciddi bir durumdur. Hastaların tama yakınında yaklaşık 4 gün süren sürekli ateş, hipotansiyon, gastrointestinal semptomlar (karın ağrısı, ishal, bulant1), döküntü, baş ağrısı, konfüzyon, miyokardit ve artmış inflamasyonla ilişkili laboratuvar bulguları ile birlikte kardiyak etkilenme ve şoka bağlı takipne, dispne görülebileceği bildirilmiştir (19-21). COVID-19 olgularının zirvesi ile PIMS olgularının zirvesi arasında birkaç haftalık fark saptanmış olması bu durumun post-enfeksiyoz bir komplikasyon olma olasılı̆̆ını akla getirmektedir (20-22). DSÖ, ABD Hastalık Kontrol ve Korunma Merkezi (Centers for Disease Control and Prevention, CDC) ve T.C. Sağlık Bakanlığ ${ }_{1}$ COVID-19 Rehberi PIMS tanı kriterleri konusunda benzerlik göstermektedir $(19,23,24)$. Ülkemizde T.C. Sağlık Bakanlığ COVID-19 Rehberine göre PIMS tanı kriterleri: $<21$ yaş hastalarda, 24 saatten uzun süren $>38.0^{\circ} \mathrm{C}$ ateş, laboratuvar tetkiklerinde inflamasyon kanıtı varlığı ile birlikte hastaneye yatış gerektirecek ağır hastalık tablosu olması, çoklu sistem tutulumu, alternatif başka tanı olma- ması ve geçirilmiş SARS-COV2 hastalığı kanıtı ya da son 4 haftada SARS-COV2 pozitif kişiye temas öyküsü olması olarak belirlenmiştir (19). Uzamış ateş ile birlikte, bulantı, kusma ve ishali olan hastalar PIMS açısından dikkatli izlenmeli, uykuya meyil ya da döküntüsü olan hastalar titizlikle değerlendirilmelidir.

\section{COVID-19 TANISI}

COVID-19 hastalığının teşhisi için temel test, üst veya alt solunum salgılarında gerçek zamanlı polimeraz zincir reaksiyonu (RT-PCR) tetkikidir. Alt solunum yollarından alınan örneklerde üst solunum yoluna kıyasla daha yüksek viral yükler tespit edilmiştir. Bu nedenle, başlangıçta nazofaringeal ya da orofarengeal sürüntüde negatif sonuç veren klinik olarak şüphelenilen durumlarda, üst solunum yolu örneklerinin tekrarı veya klinik durumuna göre ya da hasta entübe ise alt solunum yolundan örnek alınması önerilmektedir (3, 25). Dışkı örneklerinde de RT-PCR pozitifliği saptanabilse de rutin tanı ya da tarama amaçlı kullanımı önerilmemektedir (25).

Son 14 gün içerisinde, aynı ev içinde yaşadığı kişiler arasında solunum yolu enfeksiyonu tanısı ile hastaneye yatışı olan, COVID-19 tanısı alan, ateşi ve öksürügü ya da solunum sıkıntısı olan birisi olması kriterlerinin bir tanesi ile birlikte, çocuğun ateşinin olması, akciğer dinleme bulgusu varlığı, takipne varlığı, yeni başlangıçlı öksürük varlığı, oda havasinda oksijen saturasyonunun $<\% 92$ olması kriterlerinin birinin varlığında COVID-19 PCR testi istenmesi önerilmektedir. Birlikte yaşadığı kişilerden 2 veya daha fazlasinda COVID-19 tespit edilmesi, annenin gebelik döneminde COVID-19 tanısı alması ve doğum yapması, anne COVID-19 tanısı aldığı dönemde çocuğun 9 aydan küçük olması durumunda çocukta herhangi semptom aranmaksızın COVID-19 PCR testi yapılması önerilmektedir (19).

\section{LABORATUVAR}

Çocuk hastalardan elde edilen veriler göz önüne alındığında, hemogramda akyuvar sayısının genel olarak normal aralıkta olduğu, ancak lenfopeninin ve trombositopenin eşlik edebileceği bildirilmiştir. C-reaktif protein (CRP) normal veya artmış olabilir, prokalsitonin sıklıkla normaldir, prokalsitoninin yüksek olduğu olgularda sekonder bakteriyel enfeksiyon olasılığı unutulmamalıdır. Transaminaz yüksekliği, kreatin kinaz yüksekliği (CPK), laktat dehidrojenaz (LDH) yüksekliği, artmış myoglobin seviyesi, artmış prokalsitonin seviyesi, yüksek ferritin düzeyi, hipoalbüminemi, yüksek troponin seviyesi ve artmış pro-brain natriuretic peptide düzeyi, koagülopati ve artmış $\mathrm{D}$-dimer seviyesi ağır olgularda görülebilir. Bu laboratuvar bulguları olan hastalarda klinisyenler PIMS açısından dikkatli olmalıdır $(19,25,26)$. Sağlık Bakanlığı Bilim Kurulu Rehberi çocuk hastalardan 
hemogram, üre, kreatinin, sodyum, potasyum, klor, transaminaz, total bilirubin, LDH, CPK, D-dimer, troponin, CRP tetkiklerinin istenmesini önermektedir (19).

\section{GÖRÜNTÜLEME}

Temas, semptom ve dinleme bulgusu varlığında hastanın yaşı ve kliniği göz önünde bulundurularak görüntüleme metodu olarak düşük doz toraks bilgisayarlı tomografisi (BT) ya da akciğer grafisi istenebilir. Kliniğinde kötüleşme izlenen, altta yatan hastalı̆̆ olan ya da akciğer grafisi ile kliniği açılanamayan çocuklara akciğer tomografisi çekilmesi önerilmektedir (3). SARS-CoV-2 ile enfekte olan çocuklarda gözlenen BT değişiklikleri arasında, bilateral multilober konsolidasyon ve buzlu cam opasiteleri izlenmekle birlikte bu bulguların erişkinlere göre belirsiz ya da hafif olduğu bildirilmiştir (25). Toraks BT’nin normal olmasının COVID-19'u dışlamada yardımcı olduğu vurgulanmıştır $(3,19)$.

\section{TEDAVI}

Şu an için COVID-19 enfeksiyonu tedavisi için yeterli ve kesinleşmiş veriler bulunmamaktadır. Tedavi önerileri yetişkin çalışmalarına göre yapılmış olup, çocuk hastalarda ağır klinik tabloların ve ölümün nadir olması nedeniyle tedavi şemasının çocuk hastanın kliniğine göre planlanması önerilmektedir (19). Bu nedenle hastalıktan korunma ve önleme son derece önem taşımaktadır. Çocukların sıklıkla ev içi temas ile enfekte olmaları nedeni ile evlerin havalandırılması, şüpheli olguların izolasyonu, hastaların basit cerrahi maske takmaları, ev içi ve çevresel hijyen kurallarına uyulması, el hijyeninin sağlanması korunmada önemlidir (27).

Kanıtlar hızla gelişmeye devam ettikçe, tedavi önerilerini içeren rehberler güncellenmektedir. Salgının başlangıç döneminde tedavi protokollerinde azitromisin ve oseltamivir yer alırken elde edilen veriler sşığında rutin azitromisin ve oseltamivir kullanımı tedavi protokollerinden çıkarılmıştır. T.C. Sağlık Bakanlığı Bilim Kurulunun son olarak Haziran 2020 tarihinde güncellediği rehberinde ve güncel literatürde pnömoni, bakteriyel koenfeksiyon, pnömoni komplikasyonları, sepsis, septik şok, PIMS gibi durumlarda ampirik antibiyoterapi başlanması önerilmektedir (3, 19, 26-29). Çin'de 100'den fazla COVID-19 hastası çocukla yapilan çalışmada hidroksiklorokinin tedavide etkin olduğu bildirilmiştir (30). Yapılan çok merkezli çalışmalarda, olguların büyük çoğunluğunun tek başına destekleyici bakım ile düzelebildiği, potansiyel klinik risk ve kötüleşmeye göre hidroksiklorokin ya da antiviral tedavi başlanmasının doğru olacağı vurgulanmıştır (28).

T.C. Sağlık Bakanlığı Bilim Kurulu Rehberi çocuklarda tedavi kararı verirken ilaçların olası yan etkilerinin göz önünde bulundurulmasını, tedavinin her çocuk hasta için ayrı ayrı değerlendirilmesini ve olası ağır pnömonisi olan çocuklar ve risk faktörü olan hafif olgularda ilaç tedavisi planlanmasını önermektedir (19). Rehberde endikasyon varlığında ilk tercih olarak ilk gün $6,5 \mathrm{mg} / \mathrm{kg} / \mathrm{doz}$ günde 2 kez, devamında 2-5. günlerde $3,25 \mathrm{mg} / \mathrm{kg} / \mathrm{doz}$ günde $2 \mathrm{kez}$ olmak üzere oral hidroksiklorokin sülfat kullanılabileceği bildirilmiştir. Kliniğe göre lopinavir komponenti 16 mg/kg oral olmak üzere lopinavir $250 \mathrm{mg}$ /ritonavir $50 \mathrm{mg}$ tablet 10-14 gün kullanılabilir. On beş yaşından büyük çocuklarda 5 gün süre ile favipiravir $2 \times 1600 \mathrm{mg}$ yükleme, 2 x $600 \mathrm{mg}$ idame olacak şekilde tercih edilebilir (19). Hidroksiklorokin kullanımı esnasında EKG'de QTc aralığı takip edilmeli, uzun QT ya da QT aralığını uzatacak ek ilaç kullanım durumunda başlanacak tedavide yakın izlemde bulunulmalı ve seçilecek ilaç dikkatli kullanılmalı, gerekirse kesilerek alternatif tedavi düşünülmelidir. On dört günlükten küçük yenidoğanlarda lopinavir ve ritonavirin güvenlik, etkinlik, farmakokinetik profillerinin belirlenmemiş olması ve lopinavir/ritonavir oral çözeltisinin kullanımı ile propilen glikol toksisitesi gelişme riski nedeni ile tedavide önerilmemektedir (19).

Dolaşım bozukluğu olan ya da şok tablosundaki hastalarda uygun sıvı tedavisi hasta yönetiminde önem arz eder. Kalp yetmezliği ya da dolaşım bozukluğu varlığında tedaviye dobutamin $(5-15 \mathrm{ug} / \mathrm{kg} / \mathrm{dak})$ veya milrinon $(0,1-1,0 \mathrm{ug} / \mathrm{kg} /$ dak) eklenebilir. Hipotansif hastalarda epinefrin infüzyonu kullanılabilir (31). Ulusal rehberde erişkin hastalarda mikrotromboz ve buna bağlı gelişen komplikasyonların sık görülmesi nedeni ile COVID-19 tanılı tüm hastalarda aktif kanama ya da trombositopeni olmadığı sürece düşük moleküler ağırlıklı heparin (DMAH) ile tromboz profilaksisi uygulanması önerilmektedir. Çocuklarda şu an için rutin uygulamaya geçilmemekle birlikte seçilmiş hastalarda endikasyon varlığında tromboz profilaksisi yapılabilir $(3,19)$.

PIMS olgularının klinik olarak hızla kötüleşebileceği göz ardı edilmemeli, multidisipliner şekilde yakın takip edilmelidir. Yüksek oranda kardiyak tutulum nedeniyle kardiyak enzim takibi, EKG ve ekokardiyografik inceleme ile birlikte kardiyak monitörizasyon gerekir. Tedavide sıvı resüsitasyonu ve klinik gereklilik halinde inotropik destek önem taşımaktadır. Ancak eşlik edebilecek miyokardit tablosu nedeniyle sıvı tedavisinde dikkatli olunmalıdır (19,32). Olası septik şok ekarte edilemeyeceğinden ampirik olarak seftriakson ve vankomisin başlanılması önerilir $(19,33)$. Kawasaki hastalığı tanı kriterlerini karşılayan hastalarda IVIG $(2 \mathrm{gr} / \mathrm{kg})$ ve aspirin $(50-80 \mathrm{mg} / \mathrm{kg} / \mathrm{g})$ tedavileri başlanılmalıdır $(19,20)$. PIMS'de antiinflamatuar olarak kortikosteroid ve klinik gereklilik halinde interlökin-1 reseptör antagonisti anakinra tedavisi ile olumlu sonuçların alındığı bildirilmiştir $(19,32,34)$. 
Solunum desteği planlanan hastalarda bulaş riskinden dolayı non-invaziv mekanik ventilasyondan kaçınılmalıdır. Salbutamol vb. inhaler tedavi planlanmış ise ölçülü doz inhaler ya da aracı tüp ile uygulanması önerilir (3). Kritik hastalarda ECMO tedavisi, IVIG, steroid, plazma tedavisi, interferon tedavisi denenen merkezler olsa da tedavi etkinliklerini kanıtlamak ve çocuklarda spesifik tedavi protokolü oluşturmak adına daha çok ve geniş çaplı çalışmalar yapılması gerektiği vurgulanmıştır $(3,25,35)$.

\section{COVID-19 ve EMZİRE}

Anne sütü, ilk 6 ay tüm bebekler için tek başına en uygun beslenme öğesi olarak kabul edilir. SARS-CoV-2 virüsünün anne sütü ile bulaşıp bulaşmadığ 1 tam olarak belirlenememiştir. COVID-19 tanılı annelerden alınan anne sütü örneklerini inceleyen küçük hasta gruplu bir çalışmada COVID-19 PCR tetkikleri, tüm anne sütlerinde negatif olarak bulunmuş iken, bir diğer çalışmada incelenen 13 COVID-19 hastası anneden sadece birinin sütünde COVID-19 PCR pozitif saptanmış olup iki gün sonraki kontrolde tetkikin negatif olduğu bildirilmiştir (36-38). CDC anne sütü ile bulaşın belirsiz olması nedeniyle anne sütü devamını önermekle birlikte, bu kararın anne ve sağlık ekibinin koordinasyonu sonrası anne tarafindan verilmesi gerektiğini bildirmektedir. Dünya Sağlık Örgütü, CDC ve Türk Neonatoloji Derneği emzirme ya da annenin süt sağım sırasında olası damlacık enfeksiyonu ile bulaşı engelleme amacıyla annenin maske takmasını, emzirmeden önce ellerin etkin şekilde yıkanarak havlu ile kurulanmasını, meme hijyeninin sağlanmasını, süt sağma ya da toplama işlemi gerçekleştiriliyorsa materyallerin iç ve dış yüzey temizliğinin sağlanmasını, emzirilen ya da anne sütü sağılan odanın çok iyi havalandırılmasını önermektedir $(39,40)$. Anne hastanede yatmakta ise anne yatağ arasında en az 2 metre mesafenin korunması önerilmektedir $(16,17)$. Hastanede yatan annenin bebeğinden geçici olarak ayrilması söz konusu ve annenin almakta olduğu tedaviler nedeni ile emzirme kontrendikasyon taşımıyor ise bebeğin beslenmesine sağılmış anne sütü ile devam edilmesi önerilir. Gerek sağılarak, gerek formula ile beslenen çocuklara bakım veren kişilerin enfekte olmadıklarının teyid edilmesi ve bu kişilerin hijyen önerilerine uyması önemlidir (39).

\section{KORUNMA ve SOSYAL HAYAT}

Pandemi süreci nedeni ile rutin aşllama hizmetlerinin aksaması, aşı ile önlenebilir hastalıklarda salgın riskini artırmaktadır. Bu nedenle aşılama hizmetlerine aralıksız devam edilmesi son derece önemlidir. Henüz COVID-19 hastalığg için spesifik aşı geliştirilememiş olmakla birlikte Türkiye, Almanya, Fransa, Çin, Amerika başta olmak üzere birçok ülkede aşı çalışmaları devam etmektedir. İki yaş üzeri çocuklar basit yüz maskesi ile damlacık temasından korunabilir. İki yaş altı çocuklarda maske kullanımı boğulma ve kontaminasyon riski nedeni ile önerilmez (41). Oyun parklarında sosyal mesafenin korunmasına dikkat edilmelidir. Sağlık Bakanlığı Bilim Kurulu ve CDC çocukların kaydırak, salıncak vb. oyun sahası malzemelerine her teması sonrasında el hijyeninin sağlanmasını önermektedir $(42,43)$. Bugüne kadar yüzme havuzlarından COVID-19 bulaştı̆̆ bildirilmemiştir. Bununla birlikte kalabalık halde çok sayıda kullanıcının sosyal mesafe kurallarına uymadan kalabalık şekilde havuza girmesi durumunda hastalığın bulaş riskinin artacağı öngörülmektedir. Özellikle temasın fazla olduğu havuz kenarı, merdiven ve korkuluklar, soyunma odaları, duş, musluk, kapı kolları ve şezlongların temizliğinin sağlanması ve temas sonrası kişisel hijyen önlemlerinin alınması önem taşımaktadır $(42,43)$.

\section{SONUÇ}

Çocuk olguların büyük çoğunluğunun kaynağının hane halkı içinden temas yoluyla olması nedeniyle ev içi hijyen ve karantina kurallarına uyulması önem taşımaktadır. Çocuklar hastalığ 1 erişkinlere göre daha hafif bulgularla ya da asemptomatik geçirmektedir. Herhangi bir semptom taşımasalar da virüs ile enfekte çocukların hastalığın yayılmasında rol oynayabilecekleri unutulmamalıdır. COVID-19 için antiviral tedavi pediatrik hastaların çoğu için gerekli değildir. Özellikle altta yatan hastalığ 1 olan çocuklarda COVID-19 hastalığı tanısının konulması halinde hastanede yatarak tedavi edilmesi önerilir. Çocuklarda COVID-19 hastalığı ile ilişkili PIMS mortalite ve morbidite riski nedeni ile yakın takip edilmesi gereken ciddi bir tıbbi durumdur. Uzamış ateş, bulantı, kusma, ishal şikayetleri olan takibinde uykuya meyili, döküntüsü gelişen hastalarda PIMS açısından dikkatli olunmalı ve hızla tedavisi başlanmalıdır.COVID-19'un çocuklar için kanıtlanmış tedavisi olmaması nedeni ile hastalıktan korunma önlemlerinin alınması ve bu önlemlere uyulması toplum sağ lığı açısından büyük önem taşımaktadır.

\section{Etik Kurul Onayı}

İnsan ve deneysel örnek kullanılmadığından etik bir onay gerekmemiştir.

\section{Çıkar Çatışması}

Bu yazı için herhangi bir çıkar çatışması yoktur.

Finansal Destek

Makale için herhangi bir finansal destek alınmamıştır.

\section{Yazarların Makaleye Katkı Beyanı}

Yazının fikir, kaynak, yazım ve eleştirel yaklaşımı her iki yazar tarafından gerçekleştirilmiştir.

\section{Hakem Değerlendirmesi}

Hakemlerin önerileri sonrası yayınlanmaya uygun bulunmuş ve kabul edilmiştir. 


\section{KAYNAKLAR}

1. Zhu N, Zhang D, Wang W, Li X, Yang B, Song J, Zhao X, Huang B, Shi W, Lu R, Niu P, Zhan F, Ma X, Wang D, Xu W, Wu G, Gao GF, Tan W. A novel coronavirus from patients with pneumonia in China, 2019. N Engl J Med. 2020;382:727-733.

2. World Health Organization. Coronavirus disease 2019 (COVID-19). Situation Report-51. (Erişim tarihi: 1 Mayıs 2020, https://apps.who.int/iris/handle/10665/331475).

3. T.C Sağlık Bakanlığı. COVID-19 (SARS-CoV2 Enfeksiyonu) Rehberi. (Erişim tarihi: 1 Mayıs 2020, https://covid19.saglik. gov.tr/depo/rehberler/COVID-19_Rehberi.pdf).

4. Choi S-H, Kim HW, Kang J-M, Kim DH, Cho EY. Epidemiology and clinical features of coronavirus disease 2019 in children. Clin Exp Pediatr. 2020;63(4):125-132.

5. Chan JF-W, Yuan S, Kok K-H, To KK-W, Chu H, Yang J, et al. A familial cluster of pneumonia associated with the 2019 novel coronavirus indicating person-to-person transmission: a study of a family cluster. The Lancet. 2020;395(10223):514523.

6. Liu W, Zhang Q, Chen J, Xiang R, Song H, Shu S, et al. Detection of Covid-19 in children in early January 2020 in Wuhan, China. N Engl J Med. 2020;382(14):1370-1371.

7. Cao Q, Chen Y-C, Chen C-L, Chiu C-H. SARS-CoV-2 infection in children: Transmission dynamics and clinical characteristics. J Formos Med Assoc. 2020;119(3):670-673.

8. Dong Y, Mo X, Hu Y, Qi X, Jiang F, Jiang Z, et al. Epidemiology of COVID-19 among children in China. Pediatrics. 2020;145(6):e20200702.

9. Novel Coronavirus Pneumonia Emergency Response Epidemiology Team. Vital surveillances: The epidemiological characteristics of an outbreak of 2019 novel coronavirus diseases (COVID-19)-China, 2020. China CDC Weekly. 2020;2(8):113-122. (Erişim Tarihi: 2 Haziran 2020, https:// slma.lk/wp-content/uploads/2020/02/TheEpidemiologicalCh aracteristicsofanOutbreakof2019NovelCoronavirusDiseases2 8COVID-1929E28094China2C20201.pdf).

10. Bi Q, Wu Y, Mei S, Ye C, Zou X, Zhang Z, et al. Epidemiology and transmission of COVID-19 in shenzhen China: Analysis of 391 cases and 1,286 of their close contacts. Lancet Infect Dis. 2020;20:911-919.

11. Costi S, Caporali R, Cimaz R. Dealing with COVID-19 in a pediatric rheumatology unit in Italy. Paediatr Drugs. 2020;16(4):1-2.

12. Centers for Disease Control and Prevention.Coronavirus Disease 2019 in Children - United States, February 12-April 2, 2020. MMWR Morb Mortal Wkly Rep. 2020;69:422-426. (Erișim Tarihi: 20 Mayıs 2020, https://www.cdc.gov/mmwr/ volumes/69/wr/mm6914e4.htm).

13. Chen H, Guo J, Wang C, Luo F, Yu X, Zhang W, et al. Clinical characteristics and intrauterine vertical transmission potential of COVID-19 infection in nine pregnant women: a retrospective review of medical records. The Lancet. 2020;395(10226):809-815.
14. Li Q, Guan X, Wu P, Wang X, Zhou L, Tong Y, et al. Early transmission dynamicsin Wuhan, China, of novel coronavirusinfected pneumonia. N Engl J Med. 2020;382:1199-1207.

15. Cai J, Xu J, Lin D, Xu L, Qu Z, Zhang Y, et al. A Case Series of children with 2019 novel coronavirus infection: Clinical and epidemiological features. Clin Infect Dis. 2020;ciaa198.

16. Lu X, Zhang L, Du H, Zhang J, Li YY, Qu J, et al. SARS-CoV-2 infection in children. N Engl J Med. 2020;382(17):1663-1665.

17. Yonker LM, Shen K, Kinane TB. Lessons unfolding from pediatric cases of COVID-19 disease caused by SARS-CoV-2 infection. Pediatric Pulmonology. 2020;55(5):1085-1086.

18. Lee P-I, Hu Y-L, Chen P-Y, Huang Y-C, Hsueh P-R. Are children less susceptible to COVID-19? J Microbiol Immunol Infect. 2020;53(3):371-372.

19. T.C Sağlık Bakanlığı. COVID-19 (SARS-CoV-2 Enfeksiyonu) (Bilim Kurulu Çalışması) Çocuk hasta yönetimi ve tedavi rehberi. (Erişim Tarihi: 10 Haziran 2020, https://covid19bilgi. saglik.gov.tr/tr/covid-19-rehberi.html).

20. Verdoni L, Mazza A, Gervasoni A, Martelli L, Ruggeri M, Ciuffreda M, et al. An outbreak of severe Kawasaki-like disease at the Italian epicentre of the SARS-CoV-2 epidemic: An observational cohort study. Lancet. 2020;395:1771-1778.

21. Toubiana J, Poirault C, Corsia A, Bajolle F, Fourgeaud J, Angoulvant F, et al. Kawasaki-like multisystem inflammatory syndrome in children during the covid-19 pandemic in Paris, France: Prospective observational study. BMJ. 2020;369:m2094.

22. Mahase E. Covid-19: Cases of inflammatory syndrome in children surge after urgent alert. BMJ. 2020;369:m1990.

23. Centers for Disease Control and Prevention. Multisystem inflammatory syndrome in children (MIS-C) associated with coronavirus disease 2019 (COVID-19). (Erișim Tarihi: 9 Haziran 2020, https://www.cdc.gov/mis-c/hcp/).

24. World Health Organization. Coronavirus disease 2019 (COVID-19): situation report, 121. (Erişim Tarihi: 9 Haziran 2020, https://apps.who.int/iris/handle/10665/332156).

25. Zimmermann $\mathrm{P}$, Curtis $\mathrm{N}$. Coronavirus infections in children including COVID-19: An overview of the epidemiology, clinical features, diagnosis, treatment and prevention options in children. Pediatr Infect Dis J. 2020;39(5):355-368.

26. Chen, Z., Fu, J., Shu, Q. et al. Diagnosis and treatment recommendations for pediatric respiratory infection caused by the 2019 novel coronavirus. World J Pediatr. 2020;16(3):240246.

27. Singhal, T. Review of Coronavirus Disease-2019 (COVID-19). Indian J Pediatr. 2020;87(4):281-286.

28. Chiotos K, Hayes M, Kimberlin DW, Jones SB, James SH, Pinninti SG, et al. Multicenter initial guidance on use of antivirals for children with COVID-19/SARS-CoV-2. J Pediatric Infect Dis Soc. 2020; piaa045.

29. Rawson TM, Moore LS, Zhu N, Ranganathan N, Skolimowska $\mathrm{K}$, Gilchrist $\mathrm{M}$, et al. Bacterial and fungal co-infection in individuals with coronavirus: A rapid review to support COVID-19 antimicrobial prescribing. Clin Infect Dis. 2020;ciaa530. 
30. Gao J, Tian Z, Yang X. Breakthrough: Chloroquine phosphate has shown apparent efficacy in treatment of COVID-19 associated pneumonia in clinical studies. Biosci Trends. 2020;14(1):72-73.

31. Carlotti APdCP, Carvalho WBd, Johnston C, Rodriguez IS, Delgado AF. COVID-19 diagnostic and management protocol for pediatric patients. Clinics. 2020;75:e1894.

32. Hennon TR, Penque MD, Abdul-Aziz R, Alibrahim OS, McGreevy MB, Prout AJ, Schaefer BA, Ambrusko SJ, Pastore JV, Turkovich SJ, Gomez-Duarte OG, Hicar MD. COVID-19 associated multisystem inflammatory syndrome in children (MIS-C) guidelines; A Western New York approach. Prog Pediatr Cardiol. 2020;23(4):101232.

33. Rhodes A, Evans LE, Alhazzani W, Levy MM, Antonelli M, Ferrer R, et al. Surviving sepsis campaign: International guidelines for management of sepsis and septic shock: 2016. Intensive Care Med. 2017;43(3):304-77.

34. Pain CE, Felsenstein S, Cleary G, et al. Novel paediatric presentation of COVID-19 with ARDS and cytokine storm syndrome without respiratory symptoms. Lancet Rheumatol. 2020;2(7):e376-e379.

35. Bhimraj A, Morgan RL, Shumaker AH, Lavergne V, Baden L, Cheng VC-C, et al. Infectious diseases Society of America guidelines on the treatment and management of patients with COVID-19. Clin Infect Dis. 2020; ciaa478.

36. Elshafeey F, Magdi R, Hindi N, Elshebiny M, Farrag N, Mahdy S, et al. A systematic scoping review of COVID-19 during pregnancy and childbirth. Int J Gynaecol Obstet. 2020;150(1):47-52.
37. Liu W, Wang J, Li W, Zhou Z, Liu S, Rong Z. Clinical characteristics of 19 neonates born to mothers with COVID-19. Front Med. 2020;14(2):193-198.

38. Wu Y, Liu C, Dong L, Zhang C, Chen Y, Liu J, et al. Coronavirus disease 2019 among pregnant Chinese women: Case series data on the safety of vaginal birth and breastfeeding. BJOG. 2020;127(9):1109-1115.

39. Centers for Disease Control and Prevention. Care for Breastfeeding Women. (Erişim Tarihi: 14 Haziran 2020, https://www.cdc.gov/coronavirus/2019-ncov/hcp/care-forbreastfeeding-women.html).

40. Türk Neonatoloji Derneği. COVID-19 (SARS-CoV2) enfeksiyonu veya şüphesi olan yenidoğan bebeklere neonatal ve perinatal dönemde yaklaşım önerileri. (Erişim Tarihi: 14 Haziran 2020, https://www.neonatology.org.tr/ storage/2020/04/Untitled-attachment-00052.pdf).

41. Esposito S, Principi N. To mask or not to mask children to overcome COVID-19. Eur J Pediatr. 2020;179(8):1267-1270.

42. Centers for Disease Control and Prevention. Visiting Parks and Recreational Facilities. (Erişim Tarihi: 20 Haziran 2020, https:// www.cdc.gov/coronavirus/2019-ncov/daily-life-coping/ visitors.html?CDC_AA_refVal=https\%3A\%2F\%2Fwww.cdc. gov\%2Fcoronavirus\%2F2019-ncov\%2Fcommunity\%2Fparksrec\%2Fvisitors.html).

43. T.C. Sağlık Bakanlığı. COVID-19 Salgın yönetimi ve çalışma rehberi. (Erişim Tarihi: 20 Haziran 2020, https://covid19bilgi. saglik.gov.tr/tr/salgin-yonetimi-ve-calisma-rehberi.html). 